\title{
Analysis of Talent Management and Self-Efficiency of Employee Performance through Career Development at PT. Pos Indonesia (Persero) Binjai Region
}

\author{
Suci Tania Arnada ${ }^{1}$, Prihatin Lumbanraja ${ }^{2}$, Endang Sulistya Rini ${ }^{3}$ \\ 1,2,3Faculty Economics and Business, University of Sumatera Utara, Medan, Indonesia.
}

\begin{abstract}
The purpose of this study was to analyze the effect of talent management and self-efficacy on employee performance through career development at PT. Pos Indonesia (Persero) Binjai Region. This type of research is causal with a quantitative approach. The population in this study were all employees of PT. Pos Indonesia (Persero) Binjai Region, totaling 80 employees. The sampling method used is using a questionnaire and secondary data collection using SPSS with path analysis. The results of this study found that talent management has a positive and significant effect on career development. Self-efficacy has a positive and significant effect on career development. Talent management has a positive and significant effect on employee performance. Self-efficacy has a positive and significant effect on employee performance. Then indirectly talent management through career development has a positive and significant effect on employee performance and self-efficacy through career development has a positive and significant effect on employee performance at PT. Pos Indonesia (Persero) Binjai region.
\end{abstract}

Keywords: Talent Management, Self-Efficacy, Career Development and Employee

Performance

\section{INTRODUCTION}

In the current pandemic conditions, human resources (HR) are the most important priority in the company. Quality human resources will support optimization as well as effectiveness and efficiency in carrying out the tasks and responsibilities assigned to achieve company goals. Every company has goals to be achieved in the future. To achieve this goal, one of the influencing factors is employee performance. Employee performance needs to be considered by the leadership because it is very influential on the overall performance of the company. To create a good company work system, an action is needed to improve work procedures that affect employee performance.

According to Nisa (2016), employee performance is the overall value expected by the company from several different behaviors from one individual to another. A healthy company is a company that always evaluates the performance of its employees on a regular basis.

PT. Pos Indonesia (Persero) has spread throughout Indonesia, including Binjai. Employees of PT. Pos Indonesia (Persero) is required to provide the best service to the community. Faizal Rochmad as the President Director of PT. Pos Indonesia (Persero) admits that the Covid19 pandemic has greatly affected the company's performance. PT. Pos Indonesia (Persero) most affected by the Covid-19 pandemic is the business line of delivery services, logistics services, financial services and property. 
To become the best logistics service delivery company in the eyes of the public, PT. Pos Indonesia (Persero) must be able to compete with other service companies. One of the main factors in realizing the company's goals, it requires competent employees. Thus, the performance of employees should be further improved for the sake of convenience for both the company and the community.

According to Muhyi, et, al., (2016) Talent management can be a comprehensive strategic approach to identify, evaluate, develop and allocate talented human resources to assist activities in achieving the best performance of the organization. Talent Management has a philosophy that talent will distinguish how the organizational culture in a company has superior talent or not, and distinguishes a company or organization from having a competitive advantage or not.

Researchers conducted a survey to respondents as many as 30 employees to see the influence of talent management on the performance of employees of PT. Pos Indonesia is assessed based on the ability to communicate with customers because PT. Pos Indonesia (Persero) is engaged in services that require all employees to be able to communicate with customers, employee experience will also determine the current position, then employees are required to be able to make and develop policies that do not conflict with the main regulations and the existence of promotions that fair in the company. there were 30 respondents who were pre-surveyed on talent management variables, $60 \%$ of employees felt that the company did not judge based on the ability to communicate with customers, $57 \%$ of employees felt they did not have experience that was in accordance with their current position, $75 \%$ felt that employees were able to make and develop policies that does not conflict with the main regulations, and 53\% feel that not all employees receive fair treatment in promotions.
Another factor that is no less important in improving employee performance is self-efficacy. According to Alwisol (2016) self-efficacy acts as a selfperception of how well one can function in certain situations. Self-efficacy is also related to the belief that one has the ability to carry out a responsibility expected by the company. Employees who have work engagement have proactive behavior, because self-efficacy will encourage employees to take a series of effective actions to change work situations.

Researchers conducted a pre-survey of 30 employees to see how the self-efficacy of PT Pos Indonesia Binjai employees was. Where self-efficacy is a measure of an employee's belief that he is able to complete every job that can be seen from employees who believe in action in making decisions, employees are able to find the best solution in dealing with problems, employees are able to respond to situations well on every job and employees always take lessons. of every incident in the past. Based on 30 employees who conducted a pre-survey of self-efficacy variables. $60 \%$ of respondents stated that employees always believe in action in making decisions, $75 \%$ of employees are always able to find the best solution in dealing with problems, $63 \%$ of employees are always able to respond to situations well on every job and $56 \%$ of employees are always able to take lessons from every incident in the workplace. the past.

The next important factor influencing employees is career development where career development is a formal approach taken by the organization to ensure that employees in the company have the appropriate qualifications and abilities and experience when needed. Therefore, companies need to manage careers and develop them well so that employee performance is maintained.

The researcher conducted a presurvey to the respondents as many as 30 employees to see the effect of career development on the performance of the employees of PT. Pos Indonesia (Persero) 
Binjai Region is assessed based on employees who have their own career development plans, leaders who always give special attention to employee career development, companies that always provide information about various promotional opportunities available and employees who have high satisfaction with the development system career in the company. The results of the pre-survey that the author has conducted to determine career development variables through 30 employees, $75 \%$ of employees have their own career development plans, $66 \%$ of employees state that leaders always pay special attention to employee career development, $50 \%$ of companies always provide information about various promotional opportunities available. And $50 \%$ of employees have high satisfaction with the company's career development system.

\section{LITERATURE REVIEW Employee performance}

According to Gaol (2014) employee performance is a real behavior that is displayed by everyone as work performance produced by employees according to their role in the company. Meanwhile, according to Kalay (2016) employee performance is every job and working relationship between employees and the organization there is an expectation of reciprocal changes regarding inputs and results. Increased performance means good performance and will be a feedback for the company. According to Feby (2017), employee performance is the result achieved by an employee in carrying out their duties, performance is also the implementation of a plan that has been prepared by someone in carrying out their duties.

According to Mangkunegara (2016) performance is the result of work in quality and quantity achieved by an employee in carrying out his duties in accordance with the responsibilities given by the employee. According to Nisa (2016), employee performance is the overall value expected by the company from several different behaviors from one individual to another.

\section{Career development}

According to Enjang (2018), career development is a process of increasing an employee's career path through programs planned and implemented by a company. In career development there are efforts made by the company in planning employee careers, which is referred to as career management, including planning, implementing and supervising careers.

According to Andriani (2019), career development is a move to a higher position by improving work performance, education and training as well as the efforts of employees and companies to increase their potential and competence in carrying out their work through various ways, namely training, adding knowledge, experience and job promotion. Meanwhile, according to Putri (2018), career development is activities in developing the potential of employees to occupy higher positions in order to realize future career plans.

\section{Self Efficacy}

Self-efficacy is a person's assessment of his ability to deal with the duties and obligations of an employee in the company. Self-efficacy is the belief that "I can". Employees who have low self-efficacy feel they have no confidence that they can complete their work, so employees will try to avoid duties and obligations (Nugrahani, 2013).

Self-efficacy is also an employee's belief in his ability to achieve the success of a task. Employee confidence is influenced by environmental and employee cognitive factors, and individuals who have confidence in their abilities will have a great chance of success in achieving company goals (Estorina, 2018). Meanwhile, according to Ermawati (2019) self-efficacy is a form of trust that a person has in their respective capabilities to improve their work performance. Self-efficacy can be in the form of how a person feels, ways of 
Suci Tania Arnada et.al. Analysis of talent management and self-efficiency of employee performance through career development at PT. Pos Indonesia (Persero) Binjai Region.

thinking, self-motivation and the desire to have something.

\section{Talent Management}

According to Febriani (2012) talent management is a process by companies to anticipate and meet the company's needs for human resources, talent management are human resource management activities to manage talent within a company with the aim of ensuring the availability of talent supply in order to align employees right with the right job based on company goals.

According to Hammam (2020) talent management is born from the belief that talent is what distinguishes an organizational culture that is superior and what is not, as well as what distinguishes a company or organization from having a competitive advantage and what does not. Talent management according to the theory states that the people that the company wants to maintain because of their strengths.

\section{MATERIALS \& METHODS}

This type of research is a causal research with a quantitative approach. According to Sugiyono (2017) explanatory research is research that intends to explain the position of the variables studied and the relationship between one variable and another. The approach used in this research is a survey. Survey is research conducted on large or small populations, but the data studied are data taken from that population. So it is found the relative events, distributions and relationships between variables, sociological and psychological. The variables connected in this study are the dependent variable, namely employee performance $(\mathrm{Y})$, the intervening variable, namely career development (Z), and the independent variable, namely the talent management variable (X1) and self-efficacy (X2). The population in this study were employees of PT. Pos Indonesia Persero Binjai Region. According to Sugiyono (2017) The sample is part of the number of characteristics possessed by the population. In this study, the sample used was all employees of PT. Pos Indonesia Persero Binjai Region as many as 80 employees. Data analysis in this study used PLS-SEM analysis.

\section{RESULT}

\section{Respondents' Descriptive Results}

Characteristics of respondents based on gender, it can be seen that $32(40 \%)$ male respondents and 48 (60\%) female respondents. This shows that respondents with female sex are more dominant than male. This is because the needs of PT. Pos Indonesia (Persero) Binjai region has many female employees for companies engaged in services.

Characteristics of respondents based on age showed that the majority of respondents were aged 21-30 years as many as 33 employees with a percentage of $41.25 \%$, ages $41-50$ years as many as 30 employees with a percentage of $37.5 \%$, age $>50$ years as many as 4 people with a percentage of $5 \%$. In this case, employees who work at PT. Pos Indonesia (Persero) Binjai Region is a productive age because at this age employees are in a work spirit that tends to be high in reaping the results of what they have done since they first completed their education at college or high school.

Meanwhile, based on the length of work, it shows that the majority of the respondents are in the range of 1-10 years of work, totaling 58 employees with a percentage of $72.5 \%$, the length of working 11-20 years being 15 employees with a percentage of $18.75 \%$ and the length of working $>21$. year numbered 7 employees with a percentage of $8.75 \%$. And the majority of the respondents' last education was Bachelor's degree with 41 employees with a percentage of $51.25 \%$, while SMA as many as 36 employees with a percentage of $45 \%$ and Master's education as many as 3 employees with a percentage of $3.75 \%$. The number of employees with an undergraduate education background which is the standard required in the company. 
Suci Tania Arnada et.al. Analysis of talent management and self-efficiency of employee performance through career development at PT. Pos Indonesia (Persero) Binjai Region.

\section{Data Analysis Results}

Table 1 Results of Path Analysis

\begin{tabular}{|l|l|l|l|}
\hline $\begin{array}{l}\text { Proposed } \\
\text { hypothesis }\end{array}$ & $\begin{array}{l}\text { Path } \\
\text { Coefficient }\end{array}$ & Significant & Description \\
\hline $\mathrm{X} 1 \rightarrow \mathrm{Z}$ & 0,637 & 0,005 & Accepted \\
\hline $\mathrm{X} 2 \rightarrow \mathrm{Z}$ & 0,684 & 0,002 & Accepted \\
\hline $\mathrm{X} 1 \rightarrow \mathrm{Y}$ & 0,121 & 0,000 & Accepted \\
\hline $\mathrm{X} 2 \rightarrow \mathrm{Y}$ & 0,262 & 0,009 & Accepted \\
\hline $\mathrm{Z} \rightarrow \mathrm{Y}$ & 0,719 & 0,000 & Accepted \\
\hline $\mathrm{X} 1 \rightarrow \mathrm{Z} \rightarrow \mathrm{Y}$ & 0,458 & 0,005 & Accepted \\
\hline $\mathrm{X} 2 \rightarrow \mathrm{Z} \rightarrow \mathrm{Y}$ & 0,753 & 0,003 & Accepted \\
\hline
\end{tabular}

\section{DISCUSSION}

\section{The Effect of Talent Management on Career Development}

Based on the results of the hypothesis test, it shows that the talent management variable partially has a positive and significant effect on the career development variable. This is evidenced by the path coefficient value of 0.637 with a significant value for the talent management variable of 0.005 with $5 \%$, namely ( $\mathrm{p}=$ $0.005<0.05)$, meaning that talent management (X1) has a positive and significant effect on career development (Y). So that the results of this hypothesis test indicate that the hypothesis is accepted. According to Muhyi, et, al., (2016) talent management can be a comprehensive strategic approach to identify, evaluate, develop and allocate talented human resources to assist activities in achieving the best performance of the organization. In this case the company must retain its best employees who are able to occupy key positions in the company.

This research is in line with research conducted by Irmawaty (2016) which examined the Effect of Talent Management on Employee Development at the Open University which found that talent management had a positive and significant effect on career development. This study also supports the opinion of Lewis and Heckman (2006) talent management is the entire process from employee recruitment, employee placement to development and planning for employee development towards a better direction.

\section{The Effect of Self-Efficacy on Career Development}

Based on the results of hypothesis testing, it shows that the self-efficacy variable partially has a positive and significant effect on career development. This is evidenced by the path coefficient value of 0.684 with a significant value for the self-efficacy variable of 0.002 with $5 \%$, namely $(\mathrm{p}=0.002<0.05)$, meaning that self-efficacy (X2) has a positive and significant effect on career development (Z). So that the results of this hypothesis test indicate that the hypothesis is accepted. As stated in the definition by Alwisol (2016) self-efficacy acts as a self-perception of how well one can function in certain situations. Self-efficacy is also related to the belief that one has the ability to carry out a responsibility expected by the company. Employees who have work engagement have proactive behavior, because selfefficacy will encourage employees to take a series of effective actions to change work situations. Good self-efficacy will determine employee career development in the future. The higher the employee's confidence in carrying out a task and responsibility, the greater the career development that will exist in the future.

This study is in line with research conducted by Harlina, et. al (2011) who found that the self-efficacy variable had a positive and significant effect on career development. However, in contrast to the research proposed by Masyita et. al. (2020) \& Lukiyana (2019) stated that self-efficacy has a negative and significant effect on career development.

\section{The Effect of Talent Management on Employee Performance}

Based on the results of hypothesis testing, it shows that the talent management variable partially has a positive and significant effect on career development. This is evidenced by the path coefficient value of 0.121 with a significant value for the talent management variable of 0.000 with $5 \%(p=0.000<0.05)$, meaning that 
talent management (X1) has a positive and significant effect on the employee performance variable $(\mathrm{Y})$. ). So that the results of this hypothesis test indicate that the hypothesis is accepted. As stated in (Pella and Inayati, 2011) that talent management is a process to ensure a company fills key leadership positions in the future and positions that support the company's core competencies.

The research is in line with research conducted by Fatmasari (2017), Ria (2019), Hana and Heru (2018) which states that the talent management variable has a positive and significant effect on employee performance.

\section{The Effect of Self-Efficacy on Employee Performance}

Based on the results of hypothesis testing, it shows that the self-efficacy variable partially has a positive and significant effect on employee performance. This is evidenced by the path coefficient value of 0.262 with a significant value for the self-efficacy variable of 0.009 with $5 \%$ meaning $(\mathrm{p}=0.009<0.05)$ meaning that self-efficacy (X2) has a positive and significant effect on employee performance (Y). So that the results of this hypothesis test indicate that the hypothesis is accepted.

High self-efficacy will develop a strong personality in employees, reduce stress and are not easily influenced by threatening situations. This belief in selfability is a success that is always achieved, making employees work harder and always produce the best. However, this is not in line with the research conducted by Febri et. al (2017) and Jenny et. al (2016) which resulted in self-efficacy having a positive and significant effect on employee performance.

\section{The Effect of Career Development on Employee Performance}

Based on the results of hypothesis testing, it shows that the career development variable partially has a positive and significant effect on employee performance.
This is evidenced by the path coefficient value of 0.719 with a significant value for the self-efficacy variable of 0.99 with $5 \%$ meaning $(p=0.000<0.05)$ meaning career development ( $\mathrm{Z}$ ) has a positive and insignificant effect on employee performance $(\mathrm{Y})$. So that the results of this hypothesis test indicate that the hypothesis is accepted.

Based on descriptive statistical analysis of the answer variables that have been distributed to 80 employees, it shows that most respondents already have their own career development plans in the company. So it will affect employee performance significantly. Employees who have good career development will certainly have a positive effect on the performance of the employees themselves.

This research is in line with research conducted by Alvin (2018), Lukiyana and Arsinta (2019) which results in career development having a positive and significant effect on employee performance.

\section{The Effect of Talent Management on Employee Performance through Career Development}

Based on the results of the hypothesis test, it shows that the talent management variable has a positive and significant effect on employee performance through career development. This is evidenced by the path coefficient value of 0.458 with a significant value for the selfefficacy variable of 0.99 with $5 \%$ meaning $(\mathrm{p}=0.005<0.05)$ meaning talent management (X1) has a negative and significant effect on employee performance (Y) through career development (Z). So that the results of this hypothesis test indicate that the hypothesis is accepted.

This research is in line with research conducted by Abdul (2018), Lukiyana and Arsinta (2019) which states that talent management has a positive and significant effect on employee performance through career development. 


\section{The Effect of Self-Efficacy on Employee Performance through Career Development}

Based on the results of hypothesis testing, it shows that the self-efficacy variable has a positive and significant effect on employee performance through career development. This is evidenced by the path coefficient value of 0.753 with a significant value for the self-efficacy variable of 0.99 with 5\% meaning $(p=0.003<0.05)$ meaning that self-efficacy (X2) has a positive and significant effect on employee performance (Y) through career development $(Z)$. So that the results of this hypothesis test indicate that the hypothesis is accepted.

This research is in line with the research conducted by Febri et. al (2017) and Jenny et. al (2016) which resulted in self-efficacy having a positive and significant effect on employee performance. And this research is in line with research conducted by Harlina, et. al (2011) who found that the self-efficacy variable had a positive and significant effect on career development.

\section{CONCLUSION}

Based on the analysis and discussion of the Influence of Talent Management and Self-Efficacy on Employee Performance through Career Development of PT. Pos Indonesia (Persero) Binjai Region, some conclusions and suggestions can be drawn as follows:

1. Talent management has a positive and significant impact on career development

2. Self-efficacy has a positive and significant effect on career development

3. Talent management has a positive and significant effect on employee performance

4. Self-efficacy has a positive and significant effect on employee performance

5. Career development has a positive and significant effect on employee performance
6. Career development can mediate the relationship between talent management and employee performance

7. Career development can mediate the relationship between talent management and employee performance

Acknowledgement: None

\section{Conflict of Interest: None}

\section{Source of Funding: None}

\section{REFERENCES}

1. Alwisol. (2016). Psikologi Pendidikan (13th ed). Malang: UMM.

2. Andriani, I. S. (2019). Pengaruh Pengembangan Karir terhadap Kinerja Karyawan di Kementrian Agama Kabupaten Gowa. Skripsi: Alauddin Makassar.

3. Enjang, M. A. (2018). Pengaruh Pengembangan Karir, Motivasi Kerja, dan Disiplin Kerja terhadap Kinerja Karyawan Bank Syariah Mandiri Cabang Surakarta. Skripsi: Institute Negeri Salatiga. Hasibuan, M. S. P. (2017). Manajemen Sumber Daya Manusia. Jakarta: PT. Bumi Aksara.

4. Ernawati. (2019). Pengaruh Self Efficacy, Self Esteem, dan Lingkungan Kerja terhaap Kepuasan Kerja Karyawan pada PT. PLN Persero Area Bulukumba. Makassar: Universitas Negeri Alauddin.

5. Estorina. (2018). Efikasi Diri Mahasiswa Penyusun Skripsi. Yogyakarta: Universitas Sanata Dharma.

6. Fatmasari (2017). Pengaruh Talent Management dan Self Efficacy terhadap Kinerja Karyawan Distributor Alat berat. Jurnal Bisnis Darmajaya, 3(2) : 89-105.

7. Febriani, A. D. (2012). Pengaruh Talent Management terhadap Kinerja Pegawai pada Kantor Pusat PT. Bank X. Depok: Universitas Indonesia.

8. Feby, F., Sri, S., dan Dudung, A. (2017). Pengaruh Self Efficacy dan Pengembangan Karir terhadap Kinerja Karyawan di PT. Industri Telekomunikasi Indonesia (INTI) pada Divisi Corporate Services. Jurnal Administrasi Bisnis, Vol.3 No.2.

9. Gaol, L. J. (2014). A to Z Human Capital: Manajemen Sumber Daya Manusia. Jakarta: PT. Grasindo. 
Suci Tania Arnada et.al. Analysis of talent management and self-efficiency of employee performance through career development at PT. Pos Indonesia (Persero) Binjai Region.

10. Hammam, A. R. D. (2020). Analisis Pengaruh Manajemen Talenta, Self Efficacy dan Profesionalisme terhadap Kinerja Karyawan (Studi Empiris pada PT. Konimex Sukoharjo). Surakarta: Fakultas Ekonomi dan Bisnis.

11. Hanna, V. O., Heru, S. (2018). Pengaruh Manajemen Talenta terhadap Kinerja Karyawan (Studi pada Karyawan PT. Pertamina Geothermal Energy Area Uulubelu). Jurnal Administrasi Bisnis, Vol.60 No.2.

12. Hasibuan, M. S. P. (2017). Manajemen Sumber Daya Manusia. Jakarta: PT. Bumi Aksara.

13. Irmawaty., MailanI, H. (2016). Pengaruh Talent Management terhadap Pengembangan Karir Pegawai di Universitas Terbuka. Jurnal Organisasi dan Manajemen: Vol.12 No.2.

14. Jenny, F., Jonathan, P., Musdalifah, A. (2016). Pengaruh Budaya Organisasi, Pengembangan Karir dan Self Efficacy terhadap Kinerja Karyawan. Junal Manajemen, ISSN 2085-6911, Vol.8 No.1.

15. Kalay, F. (2016). The Impact of Organizational Justice on Employee Performance: A Survey in Turkey and Tturkish Context. International Journal of Human Resource Studies, Vol. 6 No.1.

16. Mangkunegara, A. P. (2016). Manajemen Sumber Daya Manusia Perusahaan. Bandung: PT. Remaja Rosdakarya.
17. Muhyi, H. A., Muttaqin, Zaenal dan Nurmalasari, Healthy. (2016). HR Plan \& Strategy. Jakarta:Swadaya Group.

18. Nisa, R. C. (2016). Pengaruh Manajemen Talenta dan Manajemen Pengetahuan terhadap Kinerja Karyawan. Jurnal Administrasi Bisnis, Vol.39 No.2.

19. Pella, D., Inayati, A. (2011). Talent Management (Mengembangkan SDM untuk Mencapai Pertumbuhan dan Kinerja Prima). Jakarta: PT. Gramedia Pustaka Utama.

20. Putri, W. A. (2018). Pengaruh Pengembangan Karir terhadap Motivasi dan Dampaknya terhadap Kinerja Karyawan (Studi Kasus di PT. Barata Indonesia (Persero) Gresik). Jurnal Ilmu Manajemen: Vol.7 No. 2.

21. Ria, A. W. (2019). Perceived Organizational Support dan Talent Management terhadap Kinerja Karyawan melalui Employe Management. Jurnal Ilmu Manajemen, Vol.7 No.4.

22. Sugiyono. (2017). Metode Penelitian Kuantitatif, Kualitatif dan R\&D. Bandung: CV Alfabeta.

How to cite this article: Suci Tania Arnada, Prihatin Lumbanraja, Endang Sulistya Rini. Analysis of talent management and selfefficiency of employee performance through career development at PT. Pos Indonesia (Persero) Binjai Region. International Journal of Research and Review. 2021; 8(12): 606-613. DOI: https://doi.org/10.52403/ijrr.20211273 